\title{
Root histogenesis in herbaceous and woody explants cultured in vitro. A critical review
}

\author{
MM Altamura \\ Dipartimento di Biologia Vegetale, Universitá di Roma 'La Sapienza', P le A Moro 5, 00185, Rome, Italy
}

(Received 30 July 1996; accepted 23 September 1996)

\begin{abstract}
Summary - Competence, determination and root meristemoid organization are key steps in adventitious rooting. A direct and indirect pattern of root formation may be present in both herbaceous and woody systems. The pattern is indirect when competence is achieved during the culture; it is direct when competent cells are present in the tissues at explanting time. Both processes may be activated in the same (herbaceous or woody) explant, and by the same tissue. A coordinated reactivation to division of cell types not directly involved in the rooting process may occur in the woody cuttings. In general, determination occurs before meristemoid formation; however, the ab initio root identity of the meristemoid has been debated. Examples of herbaceous and woody systems showing one or both rooting patterns are described. Studies on mutations affecting the specification of root meristem and on genes involved in cell cycle regulation could contribute to understanding adventitious rooting.
\end{abstract}

anatomy / histology / in vitro culture / rooting

Résumé - Histogenèse de la racine dans les explants herbacés et ligneux cultivés in vitro : une revue critique. Les étapes clés de la formation des racines adventives sont la compétence, la détermination cellulaires et l'organisation du méristémoïde. Le processus de formation des racines adventives peut être direct ou indirect dans les systèmes herbacés comme dans les systèmes ligneux. Le processus est indirect quand la compétence des cellules se réalise durant la culture. II est direct quand la compétence des cellules est déjà acquise au moment de l'explantation. Les deux types de processus peuvent être activés dans le même explant (herbacé ou ligneux), et dans le même tissu. Une réactivation coordonnée de la division cellulaire dans différents types de cellules, y compris celles qui ne sont pas concernées par la formation des racines adventives, peut se vérifier dans les systèmes ligneux. La détermination de la formation des racines adventives se réalise, en général, avant l'organisation du méristémoïde. Toutefois cela n'est pas accepté par tous les auteurs. Des exemples de systèmes herbacés et ligneux qui présentent l'un ou les deux processus de formation des racines sont donnés. L'étude des mutations qui influencent la spécificité du méristème de la racine et celle des gènes qui réglementent le cycle cellulaire pourraient aider à mieux comprendre le processus de formation des racines adventives.

anatomie / histologie / culture in vitro / rhizogenèse 


\section{INTRODUCTION}

Roots that arise in the plant from sites other than their normal sites in the embryo or the primary root are defined as adventitious, as are roots that arise on explants from stem or leaf tissues cultured in vitro. The formation of adventitious roots within tissues in which they are normally foreign requires that a cell, or group of cells, embark upon a new developmental programme. Frequently, the rooting competence of some cell types remains unexpressed in planta; however, it may be elicited through culture in vitro, as a consequence of wound reaction, per se or combined with the action of specific inducers, for instance, auxin. In genera such as willow, poplar, jasmine and citron, preformed adventitious root primordia may be already present in planta. These preformed primordia normally lie dormant until the stem is made into cuttings and placed under conditions favourable for emergence as adventitious roots.

The induction of adventitious roots is crucial for vegetative propagation via cuttings in planta or micropropagation in vitro of many species. In horticulture and forestry it allows for the cloning of superior genotypes and is an essential part of breeding programmes. However, rooting capacity varies with genotype, yet a desirable genotype may be recalcitrant, and is generally lower in woody species than in herbaceous ones (Hackett, 1988).

Histological studies on adventitious rooting have been carried out i) to identify the cells/tissues from which the roots originate (and hence are the target for auxin or other root-inducing factors); ii) to establish if preformed root primordia are present or if the site for root primordium formation needs to be created; iii) to determine if low rooting capacity is related to anatomical features (eg, the presence of a continuous ring of sclerenchyma); iv) and to relate physiological and biochemical data with the anatomical stages of root formation.

For instance, the loss or reduction of the capacity to form adventitious roots in cuttings of the mature phase, as compared to the juvenile phase, is typical of many species (eg, American elm [Schreiber and Kawase, 1975], Ficus pumila [Davies et al, 1982] and ivy [Girouard, 1967a, b]). It is well known that exogenously applied natural or synthetic auxins favour rooting, and there is evidence that this hormone is the most effective inducer of the process (Lyndon, 1990). Microscopic observations have indicated that the histology of juvenile and mature phase ivy petioles is similar prior to treatment with auxin, and show that neither can undergo cell division in the absence of this hormone (Geneve et al, 1988). Furthermore, both are responsive to auxin treatment, with the same cell type first reactivated (epithelial cells of ducts near the vascular bundles). The lack of the rooting response in the mature phase petioles is related to a limitation in the control of the location and orientation of the subsequent divisions, occurring in the cortical parenchyma, leading to a diffuse 'meristematization', and not to a localized root meristemoid formation (see later), as occurs in the juvenile phase petioles (Murray et al, 1994).

As shown in this paper, adventitious root formation is a very complex multicellular event, often involving the reactivation to cell division of cell populations not directly engaged in the formation of the root meristemoids. In vitro culture of tissue and organ systems may be useful in identifying and characterizing the many cytohistological components of this developmental process. The objectives of this paper are to review the cellular types involved in adventitious root formation from herbaceous systems (leaf explants and superficial thin cell layers of tobacco) and woody systems (stem microcuttings of easy-to-root and difficult-to-root genotypes), relating their response to specific markers of the process; and to show the sequence of events occurring in the explant and associated with root meristem formation, organization and growth.

\section{COMPETENCE AND DETERMINATION}

Competence for root formation is defined as the ability of specific cells in a tissue to respond to specific root-inducing stimuli. The molecular basis of competence is unknown; one possibility is that it reflects the expression of receptors for the root-inducing factors (Mohnen, 1994). Once competent cells have been exposed to a root inducer, they may become determined for root formation. Full determination is reached when, after being removed from the root inducer, the cells continue with root formation. Specific cell types may also be multicompetent (ie, they may exhibit different types of histogenic responses under the treatment with the root inducer). For instance, in tomato, the sheath parenchyma of the minor veins of the leaf responds in various ways to the inductive conditions, forming root meristemoids, differentiating as a starch sheath, 
forming wound vessel members, or differentiating a Casparian strip (Coleman and Greyson, 1977).

Figure 1 shows some examples of the stages through which a hypothetical tissue progresses to a final rooting response. Figure $1 \mathrm{~A}$ (top) shows the most typical situation, where competence is acquired during the culture period in the presence of a root-inductive factor (ie, it is not present in the tissue at the moment of explanting). In this case a dedifferentiation process occurs, followed by a proliferative phase. Determination is acquired, on the same culture medium, by some of the proliferated cells, marking the end of the inductive phase. The final rooting response may be obtained without changing the medium; however, in general, it is improved by removing the inducer from the medium. When the inducer is auxin, it is well known that high concentrations of the hormone are stimulatory during the inductive phase and up to the point at which root meristemoids are organized; afterwards, the hormone has an inhibitory effect (phase of elongation of the newly formed root primordia). In the example provided, it is difficult to separate competence from determination (Christianson and Warnick, 1983). Figure $1 \mathrm{~A}$ (bottom) shows that when the duration of the culture period on the inductive medium is not sufficient for determination to occur, there is no rooting response, demonstrating that determination requires much time to be

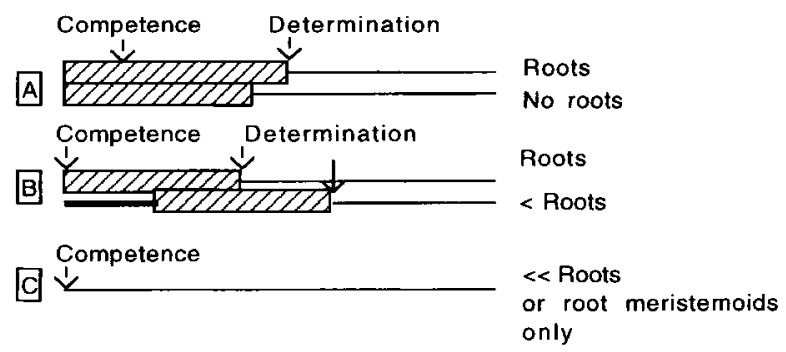

Fig 1. Diagram showing the time of competence and determination for root formation. A) Explant not competent for root formation at the beginning of the culture period. Top: Both competence and determination are achieved during the culture period on a root-inductive medium (hatched boxes). Bottom: The culture period on a root-inductive medium is insufficient for the explant to become determined. B) and C) Examples of explants competent for root formation at the beginning of the culture period. In $\mathbf{B}$, a culture period on a root-inductive medium is necessary for the explant to become determined. Top: the competent explant is cultured on a rootinductive medium (hatched boxes) from the beginning. The time required on this medium to obtain determination may be shorter than in A. Bottom: A preculture on a non-inducing hormonal medium (dark line) maintains competence and the entire time on a root-inductive medium (hatched boxes) is necessary for attainment of determination. In $\mathbf{C}$, the culture on a hormone-free medium for the entire period is sufficient per se to allow the explant to become determined; however, the rooting process may be arrested at the meristemoid stage (thin lines denote culture on hormone-free medium). completed. Furthermore, the time required for determination is dependent on the inducer (eg, type and concentration of auxin used), on cellular composition and age of the explant, and on genotype (James, 1983). Though a conditio sine qua non for rooting, competence is not the main determinant in the process (as shown below, competent cells may be already present at explanting time); instead, the pivotal role is played by determination (ie, the step at which only some of the competent cells become irreversibly canalized toward the root developmental pathway). In figure 1B competent cells are already present in the tissue at the moment of explanting. The presence of the root inducer may be necessary for a shorter time than that required for attaining competence in vitro (fig $1 \mathrm{~B}$, top, and fig $1 A$, top, for comparison), and the determination stage may be reached earlier. Figure $1 \mathrm{~B}$ (bottom) shows that preculture under hormonal conditions that are not root inductive may be unable to nullify competence for rooting in the cells. The subsequent culture under inductive conditions is able, in fact, to induce root determination, though the final response may be lower than that obtained when root-inductive conditions are present from the culture onset (fig 1B, top and bottom, in comparison). Attempts to use hormone-free medium instead of a non root-inductive hormonal condition in the preculture may be unsuccessful, because the explants may easily die or provide a very poor rooting response (Attfield and Evans, 1991b; Warnick, 1992). In figure $1 \mathrm{C}$ the hypothetical tissue possesses competent cells at the moment of explanting and is cultured in the absence of root-inducing factors for the entire period. In these conditions, the explants either die, remain alive without producing any macroscopic root or show a sporadic response. In some of these cases, histological analysis has shown that determination occurs, but the developmental pathway is arrested at the formation of root meristemoids (see later).

\section{DIRECT AND INDIRECT PATTERN FORMATION}

There are two patterns of adventitious root formation in both herbaceous and woody explants, and they reflect how competence is obtained by the explant. When competence is achieved during the in vitro culture (fig $1 \mathrm{~A}$ ) the pattern is indirect (ie, root primordia occur in a previously formed callus) (figs 2, 3D and 5). When competence is already present at culture onset (fig 
1B, C), the pattern is direct (ie, root primordia directly develop from cells in close proximity to the vascular system of the primary explant) (figs $3 \mathrm{~A}, \mathrm{~B}, 4 \mathrm{E}, \mathrm{F}$ and 6 ). It should be stressed that both direct and indirect rhizogenic processes may be activated in the same (herbaceous or woody) explant (figs 3-6). The two patterns may originate from differentiated, differentiating or meristematic cells. Examples of the cell types responsible for direct rhizogenesis in woody stem explants are shown in table I.
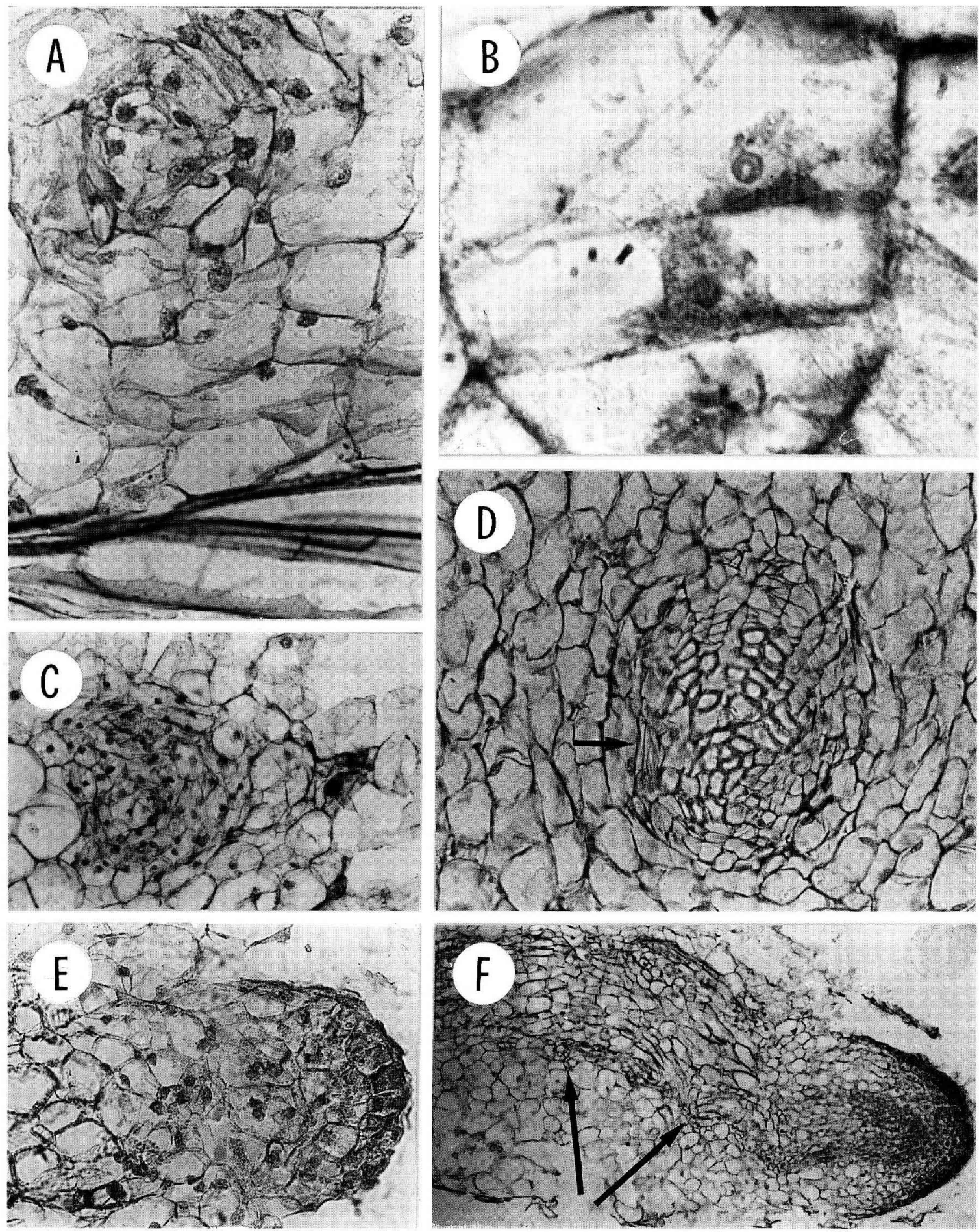

Fig 2. Indirect rhizogenesis from tobacco thin cell layers (medium with $10 \mu \mathrm{M}$ indolebutyric acid and $0.1 \mu \mathrm{M}$ kinetin; longitudinal sections of the primary explants). A-C) Successive stages of the growth of root meristemoids present in the proliferative zone due to chlorenchyma and collenchyma reactivation to cell division. In B, detail of tangential cell divisions in a meristemoid (A and B, culture day 6 ; C, culture day 24, $\times 300, \times 1200$ and $\times 225$, respectively). D) Formation of a vascular clump in the callus (culture day $26, \times$ 225). The arrow shows cambium-like cells at the boundary of the vascular elements. E-F) Successive phases of the growth of a root primordium produced at the boundary of a vascular clump. In $\mathbf{F}$, arrows show vascular strands connecting the primordium with a vascular zone in the callus (culture day 30, $\times 225$ and $\times 75$ ) (eosin and Carazzi-haemalum staining). 
Dedifferentiation is the early cellular event common to the two patterns and is necessary in differentiated and differentiating cells for the reactivation of the cell cycle. The term does not

Table I. Origin of direct adventitious roots in woody stem explants.

\section{Cambium}

Phloem parenchyma

Phloem ray

Medullary ray

Medullary sheath

Pericycle

Phloem area close to the cambium

Bud and leaf gaps

Outgrowth of the lenticels

Margin of differentiating resin ducts

Margin of differentiating secretory cavities completely express what happens in the meristematic cells. For instance, the cambial cells (table I) are already dividing cells; however, they change during the culture (eg, they change the orientation of the division planes becoming incapable of continuing the sequential production of their normal derivatives, xylem and phloem). In the indirect pattern dedifferentiation occurs in randomly located cells that are not competent. The first divisions occur as nuclear fragmentations; and the spindles of the mitotically dividing cells are randomly oriented for a large part of the culture period (Altamura et al, 1991a). This delocalized dedifferentiation in the primary explant leads to callus formation, followed by a wide 'meristematization' (the formation of superimposed meristematic layers [fig 5B], cambium-like strands and cambium-like cells surrounding de novo formed vascular clumps [figs $2 \mathrm{D}$ and $3 \mathrm{C}$ ]. In the direct pattern, dedifferentiation and mitotic divisions occur in localized groups of very few

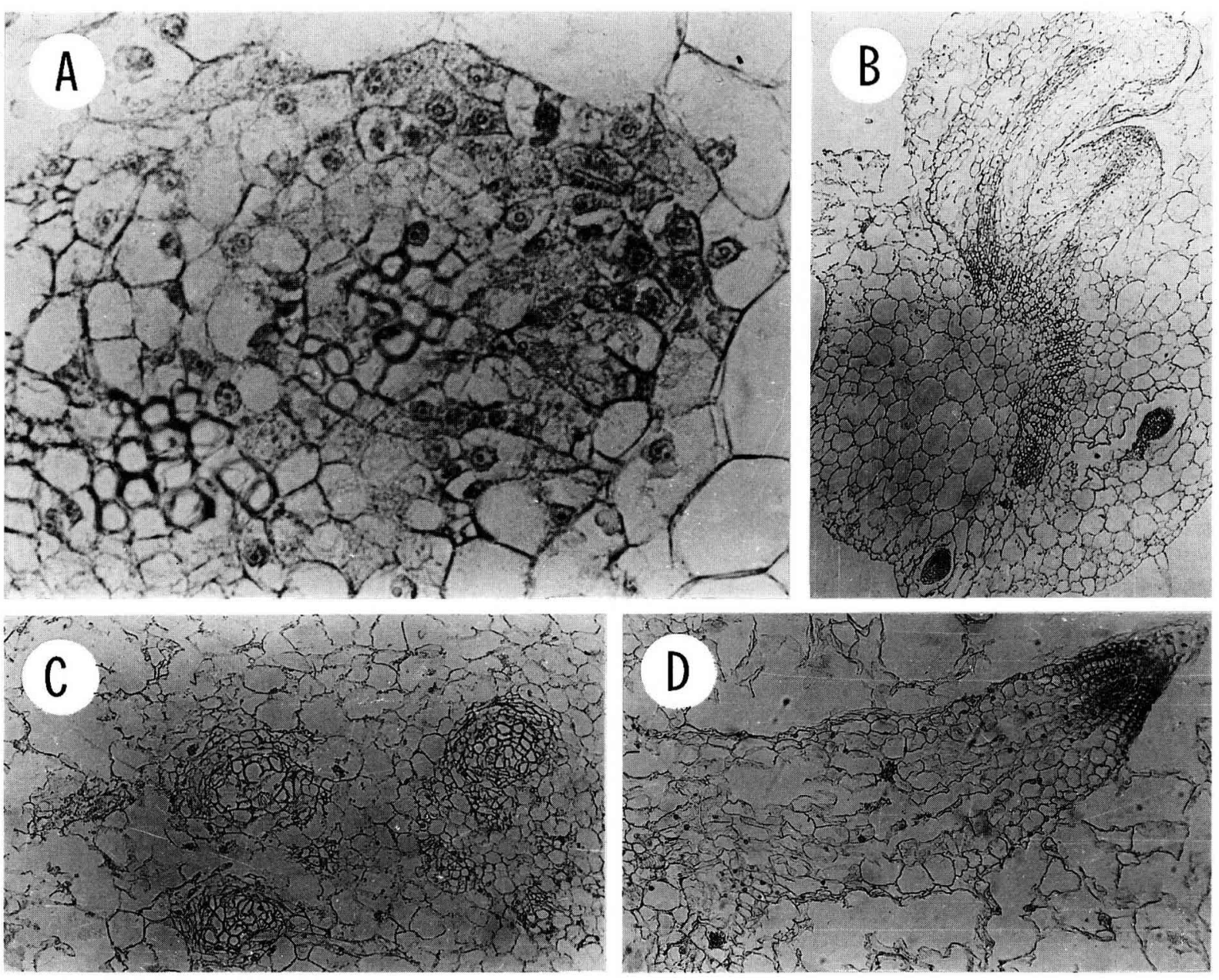

Fig 3. Direct $(A, B)$ and indirect (C, D) rhizogenesis from tobacco leaf macroexplants cultured in the presence of $0.6 \mu \mathrm{M}$ indoleacetic acid (transections of the primary explants). A) Formation of a root meristemoid after 6 days of culture due to the reactivation to cell division of the phloem parenchyma cells of the midrib $(x 360)$. B) Roots of direct genesis connected with the midrib and emerging from the explant (day 15, x 30). C) Xylogenesis in a callus region (day 15, x 62.5). D) Root of indirect genesis in the callus (day 15, $x$ 59) (eosin and Carazzi-haemalum staining). 

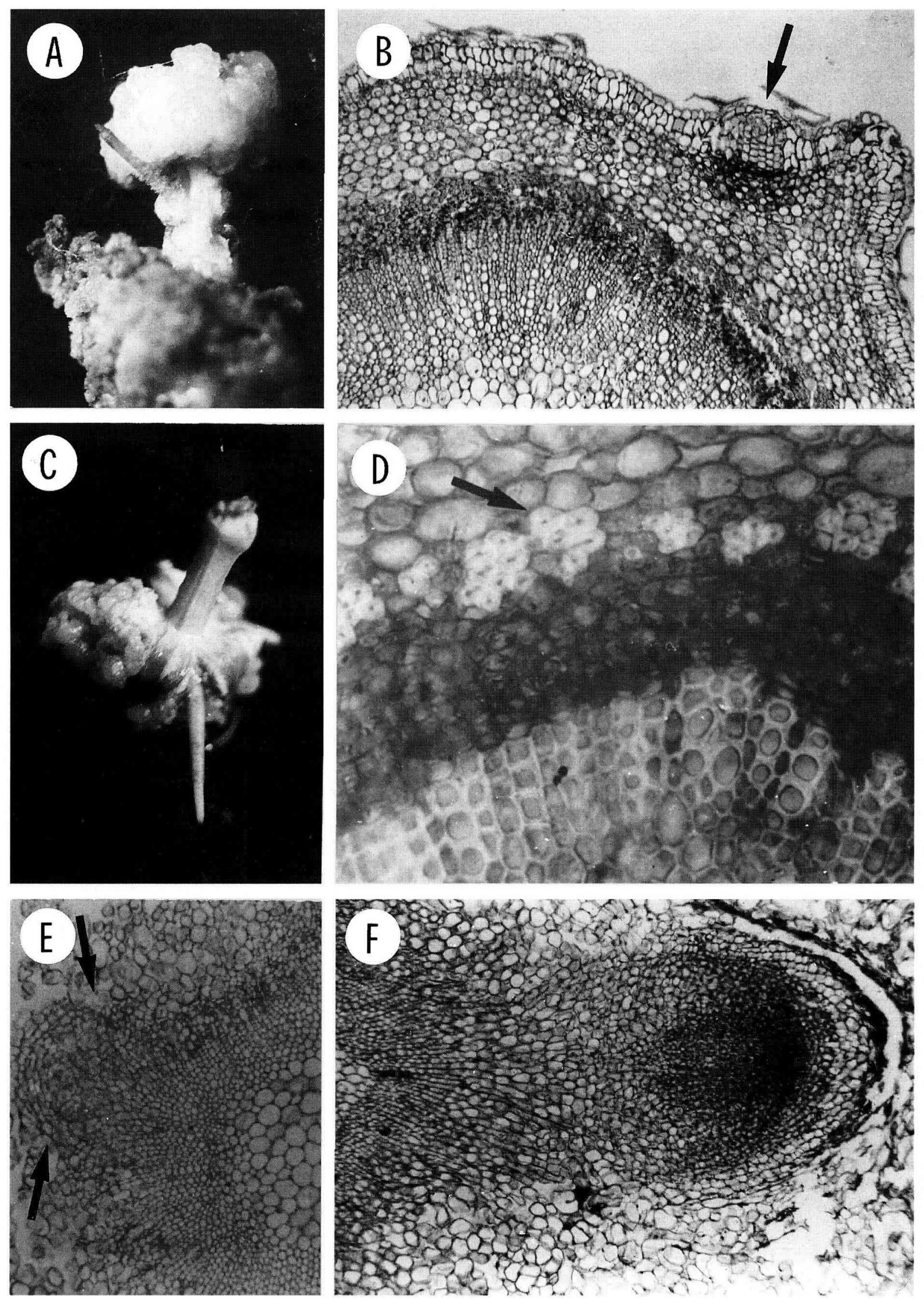

Fig 4. Rhizogenesis from internode stem explants of 2-year-old twigs of Olea europaea cultured in the presence of $5.4 \mu \mathrm{M}$ naphthaleneacetic acid (observations after 3 months of culture, when not specified). A) Root emerged from a lenticel. B) Transection of the stem with a lenticel (presumptive rhizogenic site, arrow) (day $8, \times 90$ ). C) Roots emerged from the callus at the basal cut end of the explant. D) Detail of a transection of the stem internode showing the sclerenchyma ring (arrow) (day 0, $\times$ 480). E, F) Transections of the primary explant showing a root meristematic dome (arrows) $(E)$, and a root primordium (F), of direct origin from the cambium (days 20 and 30 , respectively; $\times 90$ ) (hematoxylin-eosin staining). 

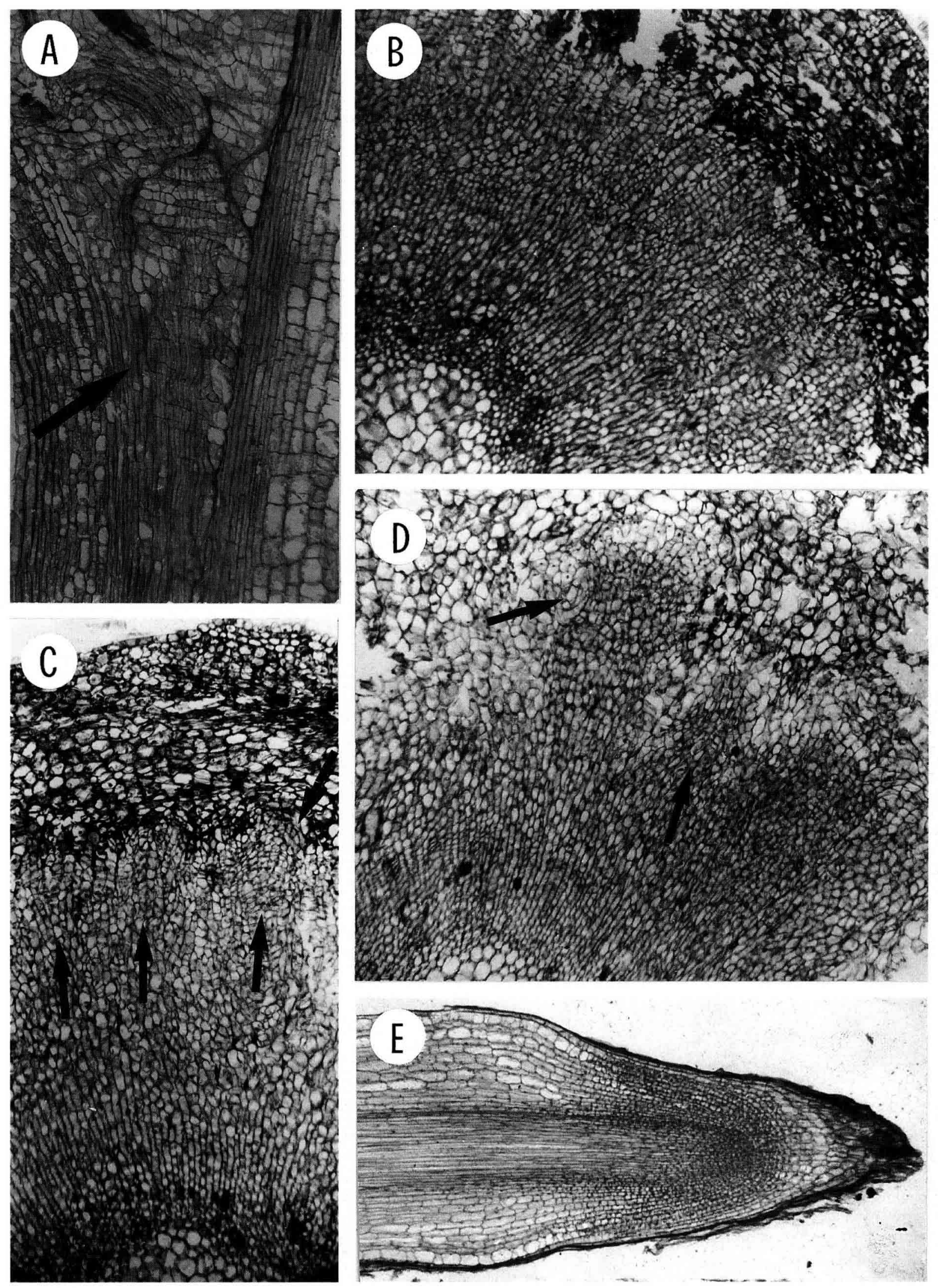

Fig 5. Indirect rhizogenesis from internode stem explants of 2-year-old twigs of Olea europaea (culture condition as in fig 4). A) Onset of callus proliferation from the cambial cells (arrow) (day 30, $\times 230$ ). B) Transection of the stem internode showing the extension of the cambium-derived callus (day 50, x 90). C) and D) Organization of meristematic domes (arrows) from the most external layers of the cambial derivatives (day 70, x 90). E) Regular structure of a root produced in the callus (day 90, $\times 90$ ) (hematoxylin-eosin staining). 
competent cells (the site of root initiation); the division planes are not randomly oriented; cell cycles are synchronized; and division activity occurs for a short time only and is followed by cell enlargement to form a root meristemoid. As discussed in the Introduction for the mature phase petioles of ivy, the control of orientation and location of cell divisions in groups of specific cells is crucial for obtaining the final rooting response (Murray et al, 1994).

\section{ROOT MERISTEMOID FORMATION AND THE DILEMMA OF ITS IDENTITY}

A key stage in adventitious rooting is the formation of root meristemoids. This stage is indepen- dent of pattern formation; meristemoids are in fact formed in both the direct (fig 3A) and the indirect (fig $2 \mathrm{~A}-\mathrm{C}$ ) processes. A root meristemoid is a clump of small cells with chromophil nuclei and nucleoli and no starch (fig 2A), growing through synchronous mitotic divisions (division plane tangential to the centre of the clump, fig $2 \mathrm{~B}$ ). In the direct process, root meristemoids derive from localized cell divisions in cells of the primary explant (fig $3 \mathrm{~A}$ ); in the indirect process, they are produced de novo in the callus (figs $2 A-C$ and $5 C, D$ ), frequently as a meristematic clump generated by the cambium-like cells at the periphery of a vascular clump (fig 2D, arrow). The same vascular clump may produce two or more root meristemoids (Altamura et al, 1991a). Both direct and indirect meristemoids may devel-
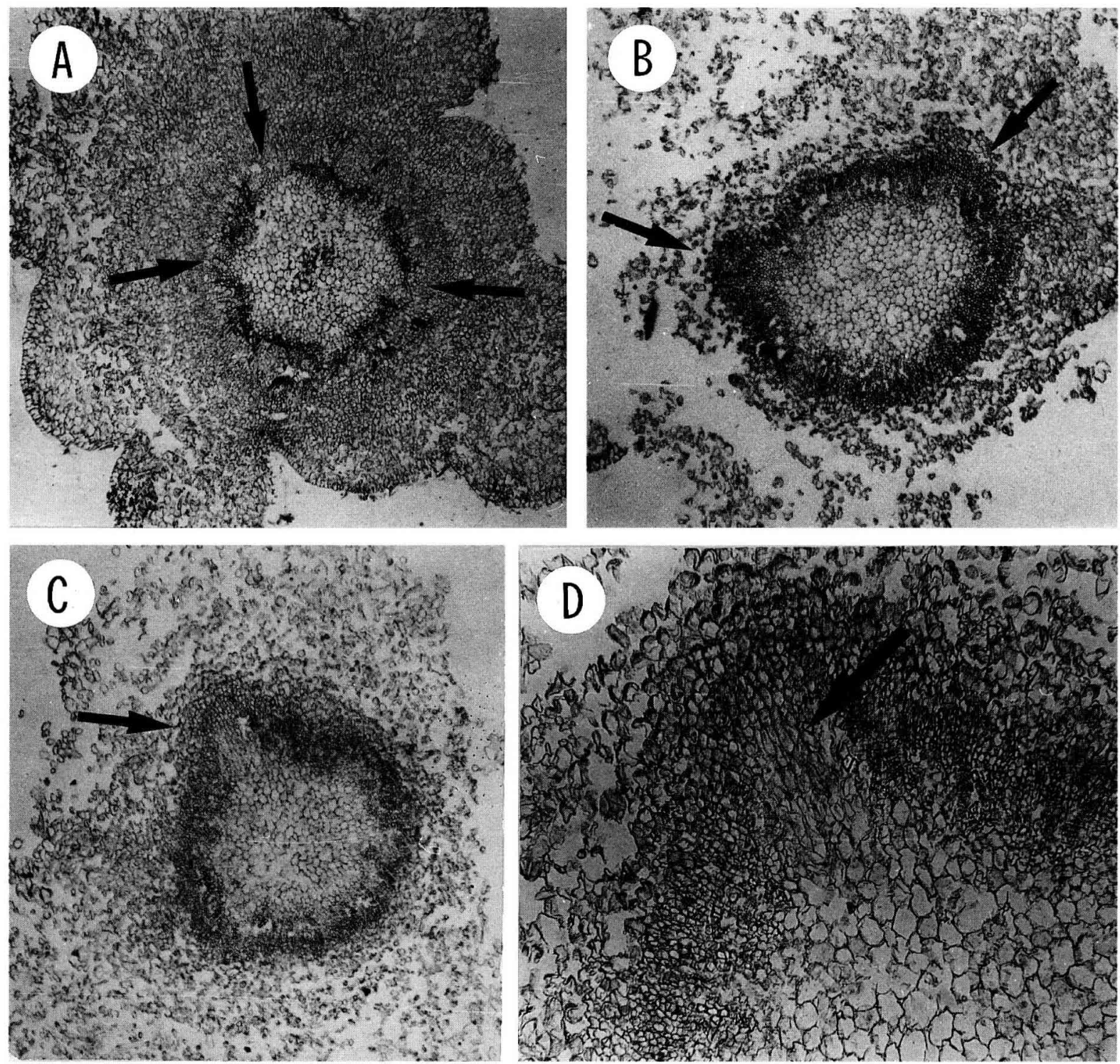

Fig 6. Direct rhizogenesis from the pith cells of internode stem explants of the olive tree (culture condition as in fig 4; observations after 3 months of culture). A) Explant widely callused showing sites of root formation (arrows) in the medullary sheath region ( $x 33$ ). B) and C) Root domes (arrows) due to the reactivation to cell division of the pith cells of the medullary sheath (x 45). D) Detail of C ( $x$ 90) (hematoxylin-eosin staining). 
op into root domes and primordia (figs $4 \mathrm{E}, \mathrm{F}$ and $6 C, D$, and $2 E, F$, respectively). Subsequent primordium development leads to root emergence (figs $3 \mathrm{D}$ and $5 \mathrm{E}$ ). When a primordium grows, it usually inhibits other meristemoids from developing into primordia; however, it does not inhibit the production of new meristemoids. As a consequence, the number of meristemoids detectable at culture end is much higher than that of the primordia, with most of the meristemoids remaining in the explant (Altamura et al, 1991a; Bellincampi et al, 1996).

It is generally believed that determination occurs in the rooting process well before meristemoids are formed, as clearly shown for Convolvulus (Christianson and Warnick, 1985; Warnick, 1992), English ivy (Geneve et al, 1988), and tobacco (Attfield and Evans, 1991a; Mohnen, 1994). According to this hypothesis, the meristemoid is born with a rooting 'nature' and is canalized toward root development from the beginning of its formation. However, the relationship between meristemoids and determination has not yet been well characterized. Some studies describe meristemoids as being developmentally plastic and thus undetermined structures (Bonnett and Torrey, 1966; Thorpe and Murashige, 1970; Ross et al, 1973; Thorpe, 1978, 1980), which become determined some time after their initiation or during their formation (Bonnett and Torrey, 1966; De Klerk et al, 1995). Less complex cell clusters, termed 'promeristemoids', have also been reported in the literature. They have been described for the early stages of caulogenesis from Pinus radiata cotyledonary explants (Villalobos et al, 1985). According to the latter authors, the meristemoids are determined structures, and the promeristemoids are developmentally plastic structures. The conflicting opinions found in the literature are due to the lack of histological studies on competence and determination and to the difficulty in recognizing meristems of organs of different types at the time of their initiation.

\section{HISTOGENESIS IN HERBACEOUS SYSTEMS}

In 1974, Tran Thanh Van and colleagues developed the technique of thin cell layer explants (TCL), which can be induced to form de novo floral buds, vegetative buds, roots or callus by regulating the auxin:cytokinin ratio, carbohydrate supply and environmental conditions. The TCL is constituted by differentiated cells only, belonging to the most superficial stem tissues (epidermis, subepidermal chlorenchyma, collenchyma and cortical parenchyma, for a total of six to eight cell layers). The histogenesis of root formation in this system has been studied at the histological and ultrastructural levels (Tran Thanh Van and Chlyah, 1976; Torrigiani et al, 1989; Altamura et al, 1991a, 1993, 1996). The rhizogenic process is indirect. The organization of the first meristemoids (fig $2 \mathrm{~A}-\mathrm{C}$ ) is preceded by a proliferative growth phase in the subepidermal and collenchyma layers. The reactivation of the cortical parenchyma layer in contact with the medium occurs late in the culture and leads to wound callus formation and the organization of vascular clumps within it (fig 2D). The cambial cells at the boundary of some vascular clumps produce root meristemoids and primordia (fig $2 \mathrm{E}, \mathrm{F}$ ). Tobacco TCLs require only 1 day of culture under rootinductive conditions to become competent and about 3 days to become determined. The meristemoids appear on the 14th day (ie, they originate as root-determined structures) (Mohnen, 1994).

In systems with an indirect rhizogenesis, such as TCL, one may wonder whether a very prolonged culture period under conditions stimulating the first phase of the process (ie, the proliferative growth) may interfere with the times of realization of competence and determination for rooting in the subsequent culture phase under inductive conditions. When TCLs are cultured for 50 days under callogenic-inductive conditions (Tran Thanh Van et al, 1974), 100\% of the explants show callus macroscopically and many vascular clumps microscopically. After only 8 days from the transfer to root-inductive conditions, a few explants already show macroscopic roots, and all the explants exhibit histologically many root meristemoids, thus showing that the time necessary for determination is shortened by the long callogenic preculture. These results show that even in explants not containing competent cells $a b$ initio, a specific hormonal pretreatment may favour the subsequent rooting response, as for explants containing competent cells ab initio (fig 1B, bottom). In the same experiment, an attempt was made to block the inhibitory role of the first elongating primordia on the development of other primordia (see earlier), prolonging by 70 days the culture phase under inductive conditions. At culture end, $100 \%$ of the explants showed macroscopic roots with a very high mean number of roots per explant (44 \pm 4 ) (Altamura and D'Angeli, unpublished results). 
The TCL system has also proven to be useful for investigating the involvement of possible biochemical markers (eg, polyamines [PA]) in the rooting process. It has been shown that the levels of free and bound putrescine and spermidine increase in TCLs when root meristemoids appear in the explants (Torrigiani et al, 1989), and inhibitors of putrescine and spermidine biosyntheses depress the rhizogenic response (Altamura et al, 1991b). Furthermore, the proliferative growth of the explants is strongly disturbed, and particular cytological events, such as cell expansion and thinning and alteration of the architecture of the cell wall, are induced when PA biosynthesis is inhibited. The addition of the corresponding PA to its inhibitor drastically reduces these events (Altamura et al, 1993, 1996).

It is known that the hairy root syndrome from Agrobacterium rhizogenes is characterized by abundant proliferation of adventitious roots from the infection site (Elliot, 1951). Among the genes of $A$ rhizogenes that have been shown to affect root differentiation (rolA, $B, C$ and $D$ ), only rolB has been shown to be capable alone of inducing adventitious rooting (Capone et al, 1989a, b). There is a relationship between this gene and auxin: the promoter of $r o l B$ is under auxin control (Capone et al, 1991), and the gene product seems to be involved in the transduction of the hormonal signal (Filippini et al, 1996). The tobacco TCL system has been shown to be useful for investigating the effects of $r o l B$ during the rhizogenic process. It has been observed that the meristemoids are much more numerous and appear sooner in rolB-transformed tissues than in wild type, thus indicating a specific effect of rolB on the promotion of meristemoid formation (Altamura et al, 1994).

Another herbaceous system widely used for histological studies on the biochemical markers of rhizogenesis is the tobacco leaf macroexplant (ie, a wide portion of the leaf including mesophyll, midrib and main veins). In contrast to the $\mathrm{TCL}$ system, specific tissues in the leaf macroexplant are able to activate both the direct (fig $3 A, B$ ) and the indirect rhizogenic processes (fig $3 \mathrm{C}, \mathrm{D}$ ). The direct process starts from the phloem parenchyma cells of the midrib and of the secondary veins, and division activity, leading to the formation of direct meristemoids (fig $3 \mathrm{~A}$ ), is highly localized. The indirect process starts from divisions occurring in randomly located cells of the parenchymas of the veins, and, rarely, in the mesophyll tissue. In the de novo formed callus, vascular clumps are generated (fig $3 \mathrm{C}$ ), and root

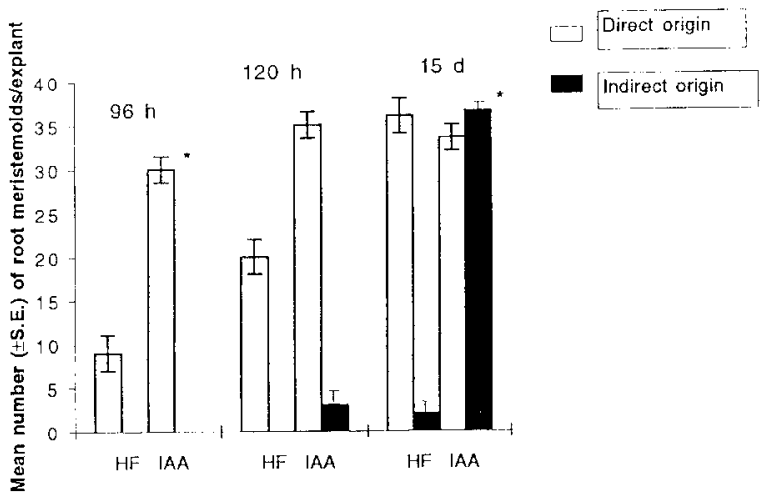

Fig 7. Formation of direct (white columns) and indirect (black columns) meristemoids in tobacco leaf macroexplants cultured for $96 \mathrm{~h}, 120 \mathrm{~h}$ and 15 days (d) under hormone-free (HF) conditions or in the presence of $0.6 \mu \mathrm{M}$ indoleacetic acid (IAA). The asterisks show $P<0.01$ differences with meristemoids of the same origin and sampling date. (Redrawn from Bellincampi et al, 1996 and Altamura et al, unpublished results).

meristemoids, indirect in nature, are produced by the cambial cells at their boundary.

Figure 7 shows an experiment in which tobacco leaf macroexplants were cultured for 15 days either under hormone-free conditions or in the presence of $0.6 \mu \mathrm{M}$ indoleacetic acid (IAA), as root inducer (Bellincampi et al, 1996; Altamura et al, unpublished results). In the latter treatment only, macroscopic roots were observed; however, the histological analysis showed that root meristemoids were also formed under hormonefree conditions. At $96 \mathrm{~h}$ in culture, meristemoids of direct genesis only were observed, and exogenous IAA greatly increased their number. At 120 $\mathrm{h}$, the first indirect meristemoids appeared in the IAA-treated explants only, while the number of direct meristemoids was not significantly different in the two treatments. At the culture end, the number of indirect meristemoids obtained in the presence of IAA highly exceeded that obtained without the hormone. Thus, the effect of exogenous IAA on root meristemoid formation in this system is to cause the formation of direct meristemoids to occur earlier and to enhance the production of indirect meristemoids. The latter effect is more than doubled by the presence of $\mathrm{rol} B$ in the explants (Bellincampi et al, 1996).

\section{HISTOGENESIS IN WOODY SYSTEMS}

Both the direct and indirect patterns of adventitious rooting are found in woody species. In general, the easy-to-root woody species exhibit the direct pattern, the roots are generated next to the 
vasculature of the primary cutting and the connection between the vascular system of the primordium and cutting is complete before the emergence of the root. The indirect genesis has been associated with difficult-to-root (recalcitrant) species (eg, Pinus radiata and Hedera helix, adult phase) (Hartmann et al, 1990). However, it is not to be excluded that a difficult-to-root species may also exhibit roots of direct genesis (see later the example of Olea europaea).

The presence of a continuous sclerenchyma ring (fig 4D), more exterior with respect to the point of origin of the root, possibly constitutes an anatomical barrier to root emergence, and such a ring has been associated with difficult-to-root cuttings, while easy-to-root types have been characterized by discontinuity in the sclerenchyma ring. However, two considerations make it possible to exclude that this anatomical barrier is the true cause of the absence of rooting in recalcitrant genotypes: auxin treatments, inducing cell expansion and proliferation, may induce breaks in the sclerenchyma ring; alternatively, the developing root primordium upon reaching the fibre band does not push through it, but instead turns downward, emerging from the cutting base (fig 4C). The true problem of the absence of a rooting response, as is the case with several recalcitrant fruit species, remains the absence of meristemoid formation (Hartmann et al, 1990). However, some anatomical peculiarities may enhance the rooting possibilities of a woody cutting (eg, the presence of resin ducts or secretory cavities, whose differentiating margins may be the site of meristemoid formation; table I, and Biondi et al, 1994). Furthermore, already in 1937 Lugovoy observed relations between lenticel anatomy and the adventitious rooting capacity of cuttings (table I and fig 4A,B).

An important consideration is that in a woody cutting a variety of different tissues exhibit an early activation in culture, even if most of them will not be sites of meristemoid formation (Harbage et al, 1993; Biondi et al, 1994). For instance, in Malus domestica 'Jork 9' cuttings, primary modifications occur in the cortical parenchyma, while the meristemoids are set up in the interfascicular region (Auderset et al, 1994). Since activation exists only a few millimeters from the cut surface, it has been suggested that wound factors play an important role, at least at the beginning of the rhizogenic process (Hicks, 1987).

In Malus domestica 'Gala' microcuttings, it has been shown that meristematic activity is confined to the basal $1 \mathrm{~mm}$ of the microcutting and that the meristemoids are formed from the phloem parenchyma cells near leaf gaps and traces (Harbage et al, 1993). The observation of a root origin from the gaps gives rise to the problem of where the cut must be made on a stem explant (ie, at the node or the internode level), and how an exogenous inductive treatment may act in different types of cut ends. Biondi et al (1994) studied the rooting response of nodes versus internodes in cherry microcuttings by comparing the number of roots produced, with or without auxin, on shoots whose cut end was a node or an internode. In this easy-to-root genotype, direct meristemoids are produced by various cell types: cells in the phloem, in the medullary sheath and in the pith rays. However, the pith cells near the leaf gaps and the cambial cells near the phloem show the highest potential to give rise to primordia. In the absence of exogenous auxin, root genesis from the leaf gaps is favoured (the number of roots per node-cut explant is five times higher than that per internode-cut one). In the presence of auxin, the rooting response is amplified in both explant types, with no difference between the two, thus showing that exogenous auxin enhances in particular the rooting potential of the phloem-sided cambial cells (Biondi et al, 1994).

The histological study of the rooting response from auxin-treated internode stem explants of the olive tree is an example of the coexistence of direct and indirect patterns of rhizogenesis in woody species (figs 4E,F and 6, and 5, respectively). In the cuttings of this genotype, defined 'recalcitrant', both rhizogenic patterns are active, and the presence of the sclerenchyma ring (fig 4D) does not constitute a barrier for the emergence of roots, since it is broken during the auxin treatment. Some roots exhibit a direct genesis from the cambial cells (fig 4E,F). Frequently, however, the cambium continues to divide, producing an internal callus (fig $5 \mathrm{~A}, \mathrm{~B}$ ). The derivatives first produced by the cambium start to divide and produce meristemoids at a point distant from the cambium (fig 5C,D), and some of them further develop as normal roots (fig $5 \mathrm{E}$ ). After callus formation and disruption of the cortex, some cells of the medullary sheath are able to activate the direct process, producing some primordia (fig 6) (Altamura, unpublished).

The root histogenesis of the olive tree stem internode cuttings clearly shows that the same tissue (the cambium) may contain both competent and non-competent cells for rooting at the time of explanting, and that competent cells, 
belonging to another cell type, may be activated also late in culture (ie, the pith cells of the medullary sheath). In this genotype the poor final macroscopic rooting probably derives from a very low number of competent cells in the explant (reduced direct response) and from very slow times of callus proliferation, and, consequently, of meristemoid formation (delayed indirect response).

\section{CONCLUSION}

The examples described histologically in the review show that more than one cellular type may be activated within an explant during the adventitious rooting process and that the number of cell types involved is higher in woody than in herbaceous cuttings. A coordinated action among different cell populations, including those not directly involved in root formation, seems to be necessary, at least in woody species, to reach the final goal of a macroscopic rooting response.

More information is needed about the states of competence and determination and about the events that cause meristemoid formation. Work in fields not directly related to adventitious root formation may provide useful information (eg, genetics and molecular biology studies on primary and lateral root meristems in planta). Various classes of mutants altering root development have been identified in Arabidopsis (Aeschbacher et al, 1994; Benfey and Scheifelbein, 1994). The study of mutations which interfere in the embryo with the specification of the root meristem (Scheres et al, 1994, 1995) may also be useful. The use of the root incompetent monogenic tobacco mutant rac seems promising for understanding the genetic basis of competence for adventitious rooting (Hackett et al, 1996). Furthermore, it could be important to examine to what extent the genes controlling the cell cycle are influenced by the mitogenic signals (auxin and wounding) of the rooting process. For example, the cdc2 gene has been found in several species and its protein kinase product is a key component of the cell cycle, required for the entry into mitosis. mRNA transcripts of this gene accumulate in the root meristem and in the initial stages of meristem activation at the sites of lateral roots, thus suggesting that $c d c 2$ expression is an early event in meristem formation (Martinez et al, 1992), linked with the state of competence to division (Hemerly et al, 1993).
In the opinion of the author of the present study, methods of screening for mutants and of tagging affected genes are the next logical step in clearly understanding the process of adventitious root formation.

\section{ACKNOWLEDGEMENTS}

The author wishes to thank Dr D Zaghi for useful collaboration.

\section{REFERENCES}

Aeschbacher RA, Schiefelbein JW, Benfey PN (1994) The genetic and molecular basis of root development. Annu Rev Plant Physiol Plant Mol Biol 45, 2545

Altamura MM, Capitani F, Serafini-Fracassini D, Torrigiani P, Falasca G (1991a) Root histogenesis from tobacco thin cell layers. Protoplasma 161, 3142

Altamura MM, Torrigiani P, Capitani F, Scaramagli S, Bagni N (1991b) De novo root formation in tobacco thin layers is affected by inhibition of polyamine biosynthesis. J Exp Bot 42, 1575-1582

Altamura MM, Capitani F, Cerchia R, Falasca G, Bagni $N$ (1993) Cytological events induced by the inhibition of polyamine biosynthesis in thin cell layers of tobacco. Protoplasma 175, 9-16

Altamura MM, Capitani F, Gazza L, Capone I, Costantino P (1994) The plant oncogene rolB stimulates the formation of flower and root meristemoids in tobacco thin cell layers. New Phytol 126, 283-293

Altamura MM, Berta G, Capitani F, Fusconi A, Falasca G, Bagni N (1996) The inhibition of polyamine biosynthesis negatively affects the endocytogenic growth pattern in tobacco rhizogenic thin layers. Plant Physiol Biochem special issue, 23

Attfield EM, Evans PK (1991a) Developmental pattern of root and shoot organogenesis in cultured leaf explants of Nicotiana tabacum cv Xanthi nc. $J$ Exp Bot 42, 51-57

Attfield EM, Evans PK (1991b) Stages in the initiation of root and shoot organogenesis in cultured leaf explants of Nicotiana tabacum cv Xanthi nc. $J$ Exp Bot 42, 59-63

Auderset G, Gavillet S, Micheli J, O'Rourke J, Ribaux M, Moncousin C (1994) Histological analysis and the evolution of biochemical markers during the in vitro rooting of Malus domestica Borkh 'Jork 9'. Adv Hort Sci 8, 5-10

Bellincampi D, Cardarelli M, Zaghi D, Serino G, Salvi G, Gatz C, Cervone F, Altamura MM, Costantino P, De Lorenzo G (1996) Oligogalacturonides prevent rhizogenesis in rolB-transformed tobacco explants 
by inhibiting auxin-induced expression of the rolB gene. Plant Cell 8, 477-487

Benfey PN, Schiefelbein JW (1994) Getting to the root of plant development: the genetics of Arabidopsis root formation. Trends Genet 10, 84-88

Biondi S, Falasca G, Altamura MM (1994) Histological study of adventitious rooting in vitro of Prunus avium microcuttings. Ann Bot (Roma) 52, 21-35

Bonnett HT, Torrey JG (1966) Comparative anatomy of endogenous bud and lateral root formation in Convolvulus arvensis roots cultured in vitro. $A m J$ Bot 53, 496-507

Capone I, Cardarelli M, Trovato M, Costantino P (1989a) Upstream non-coding region which confers polar expression to Ri plasmid root inducing gene rolB. Mol Gen Genet 216, 239-244

Capone I, Spanó L, Cardarelli M, Bellincampi D, Petit $A$, Costantino $P(1989 b)$ Induction and growth properties of carrot roots with different complements of Agrobacterium rhizogenes T-DNA. Plant Mol Biol $13,43-52$

Capone I, Cardarelli M, Mariotti D, Pomponi M, De Paolis A, Costantino P (1991) Different promoter regions control level and tissue specificity of expression of Agrobacterium rhizogenes rolB gene in plants. Plant Mol Biol 16, 427-436

Christianson ML, Warnick DA (1983) Competence and determination in the process of in vitro shoot organogenesis. Dev Biol 95, 288-293

Christianson ML, Warnick DA (1985) Temporal requirement for phytohormone balance in the control of organogenesis in vitro. Dev Biol 112, 494497

Coleman WK, Greyson RI (1977) Analysis of root formation in leaf discs of Lycopersicon esculentum Mill cultured in vitro. Ann Bot 41, 307-320

Davies FT, Lazarte JF, Joiner JN (1982) Initiation and development of roots in juvenile and mature leaf bud cuttings of Ficus pumila L. Am J Bot 69, 804811

De Klerk GJ, Keppel M, Ter Brugge J, Meekes H (1995) Timing of the phases in adventitious root formation in apple microcuttings. $J$ Exp Bot 46, 965972

Elliot C (1951) Manual of Bacterial Plant Pathogens, 2nd edn. Chronica Botanica, Waltham, MA, USA, 3-5

Filippini F, Rossi V, Marin O, Trovato M, Costantino P, Downey PM, Lo Schiavo F, Terzi M (1996) A plant oncogene as a phosphatase. Nature $379,499-500$

Geneve RL, Hackett WP, Swanson BT (1988) Adventitious root initiation in de-bladed petioles from juvenile and mature phases of English ivy. $J$ Am Soc Hort Sci 113, 630-635

Girouard RM (1967a) Initiation and development of adventitious roots in stem cuttings of Hedera helix. Anatomical studies of the juvenile growth phase. Can J Bot 45, 1877-1881
Girouard RM (1967b) Initiation and development of adventitous roots in stem cuttings of Hedera helix. Anatomical studies of the mature growth phase. Can J Bot 45, 1883-1886

Hackett WP (1988) Donor plant maturation and adventitious root formation. In: Adventitious Root Formation in Cuttings (TM Davies, BE Haissig, N Sankhla, eds), Adv Plant Sci Ser, vol 2, Dioscorides, Portland, OR, USA, 11-28

Hackett WP, Lund ST, Smith AG (1996) The use of mutants to understand competence for adventitious root initiation. 2nd Int Symp on 'The Biology of Root Formation and Development. Book of Abstracts'. Jerusalem, 6

Harbage JF, Stimart DP, Evert RF (1993) Anatomy of adventitious root formation in microcuttings of Malus domestica Borkh 'Gala'. J Am Soc Hort Sci 118, 680-688

Hartmann HT, Kester DE, Davies JT (1990) Plant Propagation. Principles and Practices, 5th edn. Prentince Hall, Englewood Cliffs, NJ, USA, 204-205

Hemerly AS, Ferreira $P$, de Almeida Engler J, Van Montagu M, Engler G, Inzé D (1993) cdc2a expression in Arabidopsis is linked with competence for cell division. Plant Cell 5, 1711-1723

Hicks GS (1987) Adventitious rooting of apple microcuttings in vitro: an anatomical study. Can J Bot 65 , 1913-1920

James DJ (1983) Adventitious root formation in vitro in apple rootstocks (Malus pumila). I. Factors affecting the length of the auxin-sensitive phase in M.9. Physiol Plant 57, 149-153

Lugovoy $M$ (1937) The rooting and non-rooting of tree species in connection with the anatomical structure of lenticels. Ukrain Akad Sci Inst Bot J 23, 239-249

Lyndon RF (1990) Plant Development. The Cellular Basis. Unwin Hyman, London, UK, 228-229

Martinez MC, Jorgensen JE, Lawton MA, Lamb CJ, Doerner PW (1992) Spatial pattern of cdc2 expression in relation to meristem activity and cell proliferation during plant development. Proc Natl Acad Sci USA 89, 7360-7364

Mohnen D (1994) Novel experimental systems for determining cellular competence and determination. In: Biology of Adventitious Root Formation (TD Davis, BE Haissig, eds), Plenum Press, New York, NY, USA, 87-98

Murray JR, Sanchez MC, Smith AG, Hackett WP (1994) Differential competence for adventitious root formation in histologically similar cell types. In: Biology of Adventitious Root Formation (TD Davis, BE Haissig, eds), Plenum Press, New York, NY, USA, 99-109

Ross MK, Thorpe TA, Costerton JW (1973) Ultrastructural aspects of shoot initiation in tobacco callus cultures. Am J Bot 60, 788-795

Scheres B, Willemsen V, Janmaat $K$, Wolkenfelt $H$, Dolan L, Weisbeek P (1994) Analysis of root development in Arabidopsis thaliana. In: NATO ASI Ser 
H81 (G Coruzzi, P Puigdomenech, eds), SpringerVerlag, Berlin, Germany, 41-50

Scheres B, Di Laurenzio L, Willemsen V, Hauser MT, Janmaat K, Weisbeek P, Benfey P (1995) Mutations affecting the radial organisation of the Arabidopsis root display specific defects throughout the embryonic axis. Development 121, 53-62

Schreiber LR, Kawase M (1975) Rooting of cuttings from tops and stumps of American Elm. Hort Sci 10, 615

Thorpe TA (1978) Physiological and biochemical aspects of organogenesis in vitro. In: Frontiers of Plant Tissue Culture. Proc 4th Int Congr Plant Tissue and Cell Culture (TA Thorpe, ed), University of Calgary Press, Calgary, Canada, 49-58

Thorpe TA (1980) Organogenesis in vitro: structural, physiological and biochemical aspects. In: International Review of Cytology. Suppl 11A (IK Vasil, ed), Academic Press, New York, NY, USA, 71-111

Thorpe TA, Murashige T (1970) Some histochemical changes underlying shoot initiation in tobacco callus cultures. Can J Bot 48, 276-285
Torrigiani P, Altamura MM, Capitani F, Serafini Fracassini D, Bagni $N$ (1989) De novo root formation in thin cell layers of tobacco: changes in free and bound polyamines. Physiol Plant 77, 294-301

Tran Thanh Van M, Dien NT, Chlyah A (1974) Regulation of organogenesis in small explants of superficial tissue of Nicotiana tabacum L. Planta 119, 149-159

Tran Thanh Van M, Chlyah A (1976) Différentiation de boutons floraux, de bourgeons végétatifs, de racines et de cal à partir de l'assise sous épidermique des ramifications florales de Nicotiana tabacum Wisc. 38. Étude infrastructurale. Can J Bot 54, 1979-1996

Villalobos VM, Yeung EC, Thorpe TA (1985) Origin of adventitious shoots in excised radiata pine cotyledons in vitro. Can J Bot 63, 2172-2176

Warnick DA (1992) Developmental biology of rhizogenesis in vitro in Convolvulus anvensis. MS Thesis, San Jose State Univ, Dept Biol Sci, San Jose, CA, USA 